\title{
Praktikalitas Media Pembelajaran Interaktif Pada Proses Pembelajaran Rangkaian Listrik
}

\author{
Doni Tri Putra Yanto \\ Jurusan Teknik Elektro, Fakultas Teknik, Universitas Negeri Padang \\ ${ }^{*}$ Corresponding author, e-mail: donitriputra@ft.unp.ac.id
}

\begin{abstract}
Abstrak - Penelitian ini membahas tentang praktikalitas media pembelajaran interaktif pada proses pembelajaran Rangkaian Listrik siswa kelas X di Sekolah Menengah Kejuruan (SMKN) 5 Padang. Penelitian ini akan mengungkap tingkat praktikalitas dari penggunaan media pembelajaran interaktif baik oleh guru maupun siswa setelah menggunakan media pembelajaran interaktif ini didalam proses pembelajaran. Subjek dalam penelitian ini adalah 2 orang guru dan 30 orang siswa. Lembaran Angket yang sudah divalidasi ahli digunakan sebagai instrumen dalam penelitian ini untuk mengumpulkan data respon guru dan respon siswa terkait dengan praktikalitas media. Data yang didapatkan diolah dengan menggunakan teknik analisis deskriftif dengan mengacu kepada langkah-langkah sistematis pengujian praktikalitas. Hasil penelitian menunjukkan bahwa berdasarkan respon guru, tingkat praktikalitas media sangat praktis, sedangkan berdasarkan respon siswa, tingkat praktikalitas media pembelajaran juga sangat praktis. Maka, dapat disimpulkan bahwa media pembelajaran interaktif sangat praktis digunakan oleh guru dan siswa dalam proses pembelajaran Rangkaian Listrik.
\end{abstract}

Kata kunci: Media Pembelajaran Interaktif, Praktikalitas, Proses Pembelajaran Rangkaian Listrik

\begin{abstract}
Thus study discusses about the practicality of interactive instructional media on Electrical Circuits Learning Process with students' grade $X$ in Technical and Vocational Middle School (SMK) 5 Padang. This research will reveal the practicality level of the use of interactive instructional media both by teachers and students after using this interactive learning media in the learning process. Subjects in this study were 2 teachers and 30 students. Questionnaire sheets that have been validated by experts were used as instruments in this study to collect teacher response data and student responses related to media practicality. The data obtained is processed using descriptive analysis techniques by referring to the systematic steps of practicality testing. The results showed that based on the teacher's response, the practicality level of the media was very practical, whereas based on the students' responses, the practicality level of learning media was also very practical. So, it can be concluded that interactive instructional media is very practical to be used by teachers and students in the Electrical Circuit learning process.
\end{abstract}

Keywords: Interactive Instructional Media, Practicality, Electrical Circuit Learning Process

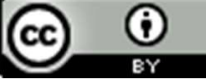

I. Pendahuluan

Media pembelajaran merupakan salah satu dari unsur-unsur yang mempengaruhi kualitas pelaksanaan pendidikan. Pemilihan dan pengunaan media yang tepat dan sesuai dengan karakteristik materi pelajaran disertai dengan penggunaan metode pembelajaran yang relevan, akan menghasilkan kualitas pelaksanaan pendidikan yang baik pula. Media pembelajaran merupakan sesuatu yang digunakan untuk menyampaikan informasi, materi pembelajaran antara pendidik dan peserta didik di dalam proses pembelajaran, media pembelajaran dapat berupa perangkat keras maupun perangkat lunak yang berfungsi membantu pendidik dalam menyampaikan materi pembelajaran dan membantu peserta didik memahami materi pembelajaran [1] dan [2].

Proses pembelajaran akan berjalan dengan baik apabila media pembelajaran dipilih dengan tepat dan adaftif dengan perkembangan ilmu pengetahuan teknologi dan seni (IPTEKS). Dalam proses pembelajaran kehadiran media pembelajaran mempunyai peran yang sangat penting. Kesulitan dalam menyampaikan materi yang bersifat abstrak, teoritis, dan umum dapat 
teratasi dengan bantuan media pembelajaran. oleh karena itu, pemilihan media pembelajaran yang baik dan tepat merupakan hal yang penting untuk memaksimalkan fungsi dari media pembelajaran teersebut dalam sebuah proses pembelajaran [3]. Kebutuhan akan media pembelajaran yang besar dan pengaruh kemajuan teknologi informasi dan komunikasi menuntut munculnya beberapa media pembelajaran baru yang terintegrasi dengan komputer maupun mobile untuk mempermudah penggunaan dan penyebaarannya. Selain itu, media pembelajaran juga harus mampu mengatasi permasalahan penyampaian materi antara pendidik dan peserta didik di dalam sebuah proses pembelajaran.

Rangkaian Listrik merupakan salah satu mata pelajaran dasar di sekolah menengah kejuruan (SMK) yang banyak membahas materi-materi pembelajaran yang bersifat konsep dan abstrak yang menuntut peserta didik untuk berkhayal mengenai sesuatu yang tidak tampak. Jika pendidik tidak mampu mengkongkretkan materi-materi yang bersifat abstak tersebut dengan baik maka peserta didik akan mengalami kesulitan untuk memahaminya. Pada akhirnya hasil belajar peserta didik akan rendah dan tidak mencapai target tujuan pelaksanaan proses pembelajaran. Hal ini dibuktikan dengan hasil observasi awal terhadap pelaksanaan proses pembelajaran Rangkaian Listrik di Sekolah Menengah Kejuruan Negeri (SMKN) 5 Padang. Pendidik mengalami kesulitan dalam menyampaikan materi pelajaran karena belum tersedianya media pembelajaran yang mampu membantu menjelaskan materi pembelajaran yang bersifat abstrak, akibatnya proses pembelajaran rangkaian listrik tidak berjalan secara optimal. Diindikasikan dengan rendahnya kemampuan kognitif peserta didik mengenai konsep-konsep rangkaian listrik.

Komunikasi pembelajaran dengan menggunakan lisan saja tidak akan mampu membantu peserta didik memahami materi pembelajaran yang bersifat abstrak, dibutuhkan suatu peralatan atau media yang mampu membantu mengkongkretkan materi yang bersifat abstrak tersebut [4], [5], dan [6]. Dengan demikian, dibutuhkan media pembelajaran yang mampu mengatasi masalah tersebut. Salah satu alternatif pilihan adalah media pembelajaran interaktif berbasis komputer sebagai bentuk media pembelajaran yang mampu mengkongkretkan materi yang bersifat abstrak serta adaftif dengan perkembangan teknologi informasi dan komunikasi. Sesuai dengan tuntutan proses pembelajaran abad 21 yang menuntut proses pembelajaran berbasis komputer dan teknologi secara terintegrasi. Media pembelajaran interaktif merupakan salah satu jawaban atas permasalahan materi pembelajaran bersifat abstrak, mengemas media pembelajaran interaktif dalam bentuk software komputer ataupun mobile serta dengan menambahkan animasi peraga yang baik akan menarik keinginan peserta didik untuk belajar dan memahami konsep pembelajaran yang berisfat abstrak. Selain itu, media pembelajaran interaktif merupakan wujud media pembelajaran yang adaftif dengan perkembangan teknologi tuntuntutan belajar pada abad 21. [7-10].

Menurut [10] dan [11] Media pembelajaran sebelum digunakan harus melalui beberapa proses pengujian agar media pembelajaran yang dihasilkan benar-benar mampu mengatasi permasalahan dalam pelaksanaan proses pembelajaran. salah satu proses tersebut adalah pengujian praktikalitas media.

\section{Studi Pustaka}

Belajar adalah suatu proses yang kompleks yang terjadi selama hidup seseorang. Proses belajar itu terjadi karena adanya interaksi seseorang dengan lingkungannya. Menurut ulasan [11], Belajar adalah proses perubahan tingkah laku melalui interaksi antara individu dan lingkungan. Sedankan menurut ulasan [12] Belajar adalah perubahan tingkah laku atau penampilan, serangkaian kegiatan misalnya dengan membaca, mengamati, mendengarkan, meniru dan sebagainya. Berdasarkan uraian diatas dapat disimpulkan bahwa belajar merupakan hasil dari pengalaman yang telah dilewati oleh seorang siswa. Belajar juga merupakan proses perubahan tingkah laku siswa setelah adanya interaksi antara siswa dengan lingkungan sekitar.

Media Pembelajaran merupakan gabungan dari dua kata yakni media dan pembelajaran. Berdasarkan ulasan [13] dan [14] mengemukakan bahwa kata media berasal dari bahasa latin dan merupakan bentuk jamak dari kata "medium" yang secara harfiah berarti perantara. Jadi media adalah perantara atau pengantar pesan dari pengirim ke penerima pesan. Sedangkan menurut [1] kata media berasal dari bahasa latin medius, yang secara harfiah berarti 'tengah', 'perantara' atau 'pengantar'. Dalam bahasa arab, media adalah perantara (waasaailah) atau pengantar pesan dari pengirim kepada penerima pesan. Oleh karena itu, secara bahasa media dapat dikatakan sebagai alat perantara atau pengatar suatu pesan dari pemberi pesan kepada penerima pesan. Alat tersebut dapat 
berbentuk perangkat keras (hardware) maupun perangkat lunak (software). Penyampaian pesan ini bisa dilakukan melalui simbol-simbol komunikasi berupa simbol-simbol verbal dan non-verbal atau visual, yang selanjutnya ditafsirkan oleh penerima pesan.

Media pembelajaran secara umum berfungsi untuk mempermudah penyampaian materi pembelajaran dari seorang pendidik ke peserta didik sehingga dapat membantu guru dan mempermudah pemahaman siswa dalam proses pembelajaran, hal ini sejalan dengan pendapat [15] dan [16] yang menyatakan bahwa media pembelajaran yang baik akan dapat meningkatkan proses belajar siswa dalam proses pembelajaran yang pada gilirannya diharafkan mampu meningkatkan hasil belajar siswa. Penggunaan media Pembelajaran akan sangat membantu keefektifan proses pembelajaran dan penyampaian informasi (pesan dan isi pelajaran) pada saat itu. Kehadiran media dalam pembelajaran juga dikatakan dapat membantu peningkatan pemahaman siswa, penyajian data/informasi lebih menarik dan terpercaya, memudahkan penafsiran data, dan memadatkan informasi. Jadi dalam hal ini dikatakan bahwa fungsi media adalah sebagai alat bantu dalam proses pembelajaran.

Interaktif adalah hal yang terkait dengan komunikasi dua arah. Suatu hal bersifat saling melakukan aksi dan reaksi, saling aktif dan saling berhubungan serta mempunyai timbal balik antara yang satu dengan yang lainnya. Sedangkan dalam istilah komputer, kata interaktif berarti dialog antara komputer dan komputer atau antara komputer dengan terminal [4], [17], dan [18]

Media pembelajaran interaktif menurut [5] dan [17] adalah suatu bentuk media pembelajaran yang dalam penggunaanya dapat menimbulkan keterkaitan antara pengguna dengan media pembelajaran terebut dengan saling memberikan pengaruh serta saling memberikan aksi dan reaksi antara yang satu dengan yang lainya dalam membantu menyampaikan materi pembelajaran. Dengan kata lain dapat dikatakan bahwa media pembelajaran interaktif merupakan suatu alat perantara penyampaian materi pembelajaran oleh guru kepada siswa dimana pada penggunaannya menimbulkan interaksi antara siswa dengan media dengan cara saling berkaitan serta saling memberikan aksi dan reaksi antara yang satu dengan yang lainnya. Berdasarkan pengertian media pembelajaran interaktif tersebut maka dapat diketahui bahwa media pembelajaran interaktif ini merupakan salah satu media pembelajaran yang dapat membantu menjelaskan materi-materi pembelajaran yang bersifat abstrak atau dengan kata lain mengkongkretkan hal yang bersifat abstrak kepada siswa akibat pengaruh saling memberikan aksi dan reaksi antara yang satu dengan yang lainnya.

Praktikalitas adalah keterpakaian media pembelajaran yang telah dikembangkan. Untuk mengetahui praktikalitas dari media pembelajaran yang telah dikembangkan maka peneliti melakukan uji coba produk. Peneliti melakukan uji coba produk di SMKN 5 Padang. Praktikalitas diperoleh dari hasil analisis data pengamatan proses pembelajaran dengan menggunakan media pembelajaran yang telah dinyatakan valid oleh validator. Kemudian untuk mengetahui praktikalitas media pembelajaran interaktif ini maka diminta respon guru dan respon siswa setelah menggunakan media pembelajaran ini dalam proses pembelajaran. Pengujian praktikalitas dilakukan dengan tujuan untuk mengetahui keterpakaian media pembelajaran tersebut dalam suatu proses pembelajaran.

\section{Metode}

\section{A. Jenis Penelitian}

Jenis penelitian yang digunakan pada penelitian ini adalah penelitian kuantitatif. Pengujian terhadap praktikalitas sebuah produk yang bertujuan mengungkap tingkat praktikalitas produk setelah dilakukan proses ujiocoba. Bentuk pengujian ini merupakan bagian dari penelitian Pengembangan atau Research and Development $(\mathrm{R}$ \& D).

Teknik pengumpulan data yang digunakan adalah dengan pengisian lembaran angket praktikalitas oleh subjek penelitian. Data dari subjek penelitian yang kemudian diolah untuk pengambilan keputusan mengenai praktikalitas media pembelajan interaktif. [19] dan [20]. Praktikalitas adalah keterpakaian media pembelajaran yang telah dikembangkan. Untuk mengetahui praktikalitas dari media pembelajaran yang telah dikembangkan maka peneliti melakukan uji coba produk. Peneliti melakukan uji coba produk di SMKN 5 Padang. Kemudian untuk mengetahui praktikalitas media pembelajaran interaktif ini maka diminta respon guru dan respon siswa setelah menggunakan media pembelajaran ini dalam proses pembelajaran.

\section{B. Subjek Penelitian}

Subjek dalam penelitian ini terdiri dari 2 orang guru yang mengajar pada proses pembelajaran Rangkaian Listrik dan 30 orang Siswa yang 
mengikuti proses pembelajaran Rangkaian Listrik kelas X di SMKN 5 Padang dengan kompetensi keahlian Teknik Instalasi Tenaga Listrik (TITL).

\section{Instrumen Penelitian}

Instrumen penelitian yang digunakan pada penelitian ini adalah Lembaran angket praktikalitas. Lembaran angket praktikalitas dibagi menjadi dua yaitu lembaran angket praktikalitas untuk guru dan lembaran angket praktikalitas untuk siswa. Lembaran angket praktikalitas untuk guru diisi oleh guru tentang kepraktisan dan kemudahan penggunaan media pembelajaran interkatif dalam proses pembelajaran. lembar angket praktikaslitas media oleh guru berisikan tentang kemudahan penggunaan media, waktu yang digunakan, mudah diinterprestsikan, memiliki daya tarik, serta dapat digunakan sebagai pembelajaran mandiri. Sedangkan lembaran angket praktikalitas media untuk siswa diisi oleh siswa setelah menggunakan media pembelajan interaktif dalam proses pembelajaran. Instrumen ini berisikan tentang kemudahan siswa dalam memahami materi, kemudahan siswa dalam penggunaan media, waktu yang digunakan, daya tarik media, serta dapat digunakan secara mandiri oleh siswa selama proses pembelajaran berlangsung. Lembaran angket praktikalitas media pembelajaran interaktif yang digunakan dalam penelitian ini disusun dan didesain dengan mengacu kepada kisi-kisi angket. Teknik ini bertujuan agar instrumen penelitian yang digunakan dapat mengukur dengan baik selama pengguanaannya dalam penelitian. Kisikisi lembaran angket praktikalitas media pembelajaran interaktif untuk guru disajikan pada Tabel 1. Sedangkan kisi-kisi lembaran angket media pembelajaran interaktif untuk siswa disajikan pada tabel 2.

Tabel 1. Kisi-Kisi Instrumen Praktikalitas untuk Guru

\begin{tabular}{cl}
\hline No & \multicolumn{1}{c}{ Indikator } \\
\hline 1 & Kemudahan penggunaan media \\
2 & Efisiensi waktu \\
3 & Mudah diinterprestasikan \\
4 & Kesesuiaan dengan materi \\
5 & Daya tarik \\
6 & Dapat digunakan sebagai pembelajaran \\
& mandiri \\
\hline
\end{tabular}

Tabel 2. Kisi-Kisi Instrumen Praktikalitas untuk Siswa

\begin{tabular}{cc}
\hline No & Indikator \\
\hline 1 & Kemudahan penggunaan media \\
\hline
\end{tabular}

Efisiensi waktu

Kesesuiaan dengan materi

Daya tarik

Dapat digunakan sebagai pembelajaran mandiri

Lembaran angket praktikalitas media pembelajaran ini disusun berdasarkan kisi-kisi yang telah dikemukakan tersebut. Setelah lembaran angket praktikalitas selesai didesain dan disusun, sebelum digunakan sebagai instrumen pengumpul data dalam penelitian, harus terlebih dahulu di validasi oleh ahli. Dalam penelitian ini validasi lembaran angket praktikalitas media pembelajaran interaktif dilakukan oleh Dr. Ridwan, M.Sc.Ed. dan Dr. Usmeldi, M.Pd. Berdasarkan hasil validasi maka didapatkan lembar praktikalitas media pembelajaran interaktif yang terdiri dari 7 item pernyataan untuk guru dan 16 item pernyataan untuk siswa. Masing-masing instrumen disusun dengan pilihan respon menggunakan skala 5 (skala likert).

\section{Teknik Analisis Data}

Teknik Analisis data yang digunakan pada penelitian ini adalah teknik analisis deskriptif dengan mengacu kepada langkah-langkah yang dikemukakan oleh [18] sama halnya dengan yang dilaksanakan [19] dan [20]. Hasil penilaian melalui angket terhadap media pembelajaran interaktif dari guru dan siswa. Penilaian tersebut akan memperoleh tangapan atau pendapat dari guru dan siswa untuk menentukan praktikalitas media pembelajaran interaktif setelah diterapkan dalam proses pembelajaran. Angket terdiri dari pernyataan-pernyataan untuk menentukan praktikalitas media serta disediakan alternatif jawaban terhadap pernyataan-pernyataan tersebut. Alternatif jawaban terdiri dari sangat setuju, setuju, ragu-ragu, kurang setuju, dan tidak setuju.

[18] mengemukakan bahwa kepraktisan media dianalisis dengan menggunakan statistik deskriptif dan dilakukan dengan mengikuti beberapa langkah-langkah sebagai berikut:

1. Skor Jawaban dengan kriteria sebagai berikut:

$$
\begin{aligned}
& 1=\text { Sangat Tidak Setuju } \\
& 2 \text { = Tidak Setuju } \\
& 3=\text { Ragu-ragu } \\
& 4=\text { Setuju } \\
& 5=\text { Sangat Setuju }
\end{aligned}
$$

2. Menentukan skor rata-rata yang didapat dengan cara menjumlahkan nilai yang didapat dari banyak indikator 
3. Skor maksimum pada masing-masing item praktikalitas nilainya adalah 5

4. Pemberian nilai praktikalitas dengan rumus :

$$
\% \text { Praktikalitas }=\frac{\text { Nilai total }}{\text { Nilai maksimum }} \times 100 \%
$$

5. Memberikan penilaian terhadap praktikalitas multimedia interaktif ini dengan kriteria disajikan pada tabel 3 .

\section{Tabel 3. Klasifikasi Tingkat Praktikalitas}

\section{HASIL DAN PEMBAHASAN}

Media pembelajaran interaktif merupakan media pembelajaran yang dibuat dalam bentuk software berbasis komputer yang dilengkapi dengan fitur materi pelajaran, simulasi dengan animasi interaktif untuk materi yang abstrak, soal tes yang disertai dengan jawaban, serta dibuat dengan kemudahan dalam mengoperasikannya. Media pembelajaran interaktif ini pada saat proses pembelajaran digunakan oleh siswa dan guru, pada saat proses pembelajaran berlangsung siswa terlibat interaksi secara langsung dengan media pembelajaran yang digunakan. Salah satu tampilan dari media pembelajaran interaktif yang akan diuji praktikalitas pada penelitian ini disajikan pada gambar 1. Data yang didapatkan dalam penelitian ini dibagi menjadi dua kelompok yaitu data respon praktikalitas media pembelajaran interaktif dari guru dan data respon praktikalitas media pembelajaran interaktif dari siswa. Data

\begin{tabular}{ccc}
\hline No & $\begin{array}{c}\text { Tingkat } \\
\text { Pencapaian }(\%)\end{array}$ & Klasifikasi \\
\hline 1 & $81-100$ & Sangat Praktis \\
2 & $61-80$ & Praktis \\
3 & $41-60$ & Cukup Praktis \\
4 & $21-40$ & Kurang Praktis \\
5 & $0-20$ & Tidak Praktis \\
\hline
\end{tabular}

didadapatkan setelah dilakukan pengisian lembar angket praktikalitas oleh subjek penelitian.

\section{A. Data Respon Guru}

Data respon guru merupakan data hasil pengisian angket praktikalitas oleh guru setelah menggunakan media pembelajaran interaktif dalam proses pembelajaran Rangkaian Listrik yang terdiri dari 2 orang guru, data yang didapatkan kemudia dianalisis dengan menggunakan analisis deskriftif dengan mengacu kepada langkahlangkah yang dikemukakan oleh [18]. Berdasarkan analisis data hasil pengisian angket oleh guru maka didapatkan nilai praktis dari media pembelajaran interaktif secara keseluruhan oleh guru sebesar 95,7. Jika di interprestasikan dengan tabel nilai praktikalitas, maka praktikalitas media pembelajaran interaktif oleh guru berada pada taraf sangat praktis. Hasil analisis data praktikalitas media pembelajaran interaktif oleh guru untuk masing-masing item pernyataan angket disajikan pada tabel 4 .

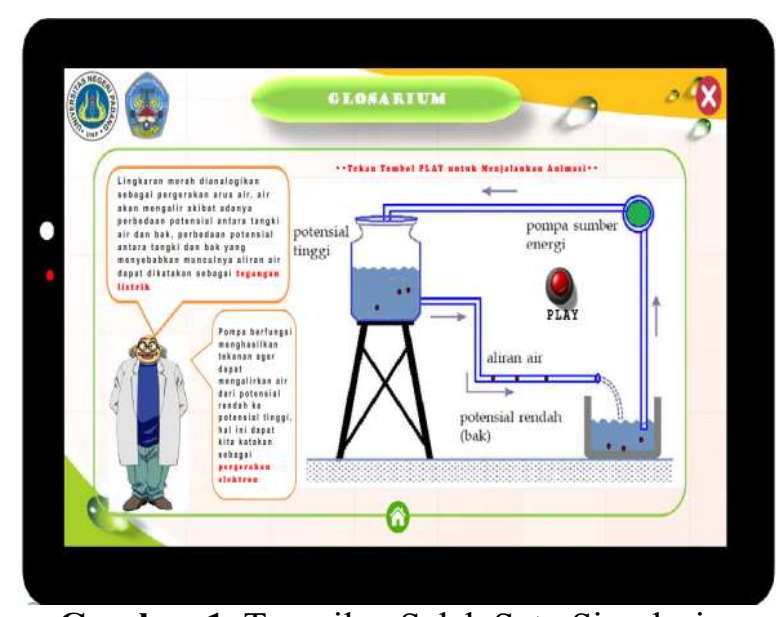

Gambar 1. Tampilan Salah Satu Simulasi pada Media Pembelajaran Interaktif

Tabel 4 . Data Praktikalitas dari Respon Guru

\begin{tabular}{ccl}
\hline Item & $\begin{array}{c}\text { Nilai } \\
\text { Praktikalitas }\end{array}$ & Interprestasi \\
\hline 1 & 100 & Sangat Praktis \\
2 & 100 & Sangat Praktis \\
3 & 100 & Sangat Praktis \\
4 & 100 & Sangat Praktis \\
5 & 90 & Sangat Praktis \\
6 & 100 & Sangat Praktis \\
7 & 80 & Sangat Praktis \\
\hline Total & 95,7 & Sangat Praktis \\
\hline
\end{tabular}

Berdasarkan tabel hasil analisis data pada tabel 4, maka dapat diketahui bahwa tingkat praktikalitas untuk masing-masing item pernyataan pada angket berada pada taraf sangat praktis, serta didukung dengan nilai total kepraktisan media pembelajaran interaktif yang berada pada taraf sangat praktis, dengan demikian maka media pembelajaran interaktif sangat praktis digunakan oleh guru dalam proses pembelajaran Rangkaian Listrik. Penyebaran data untuk masing-masing item disajikan dalam grafik praktikalitas dari respon guru yang disajikan pada gambar 2 . 


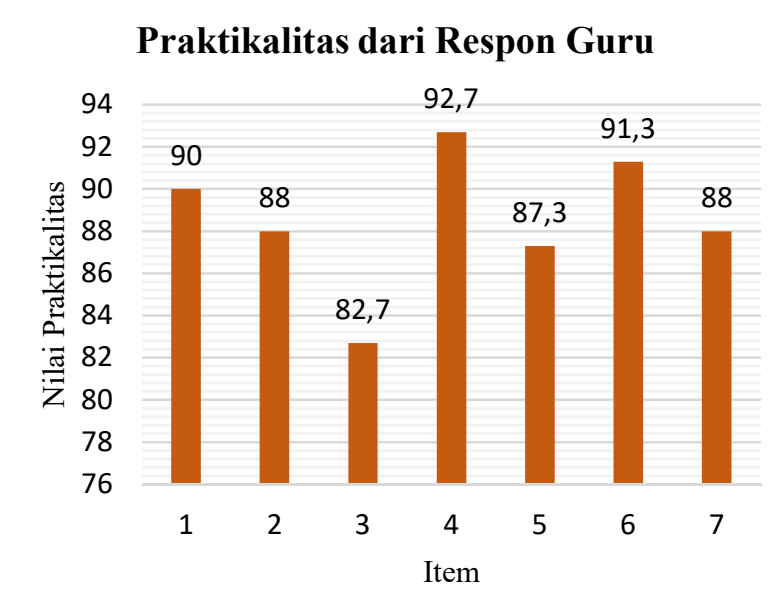

Gambar 2. Grafik Praktikalitas Media berdasarkan Respon Guru

\section{B. Data Respon Siswa}

Data respon siswa merupakan data hasil pengisian angket praktikalitas oleh siswa setelah menggunakan media pembelajaran interaktif dalam proses pembelajaran Rangkaian Listrik yang terdiri dari 30 orang siswa. Data siswa sangat diperlukan dalam penelitian ini karena media pembelajaran interaktif dibuat bukan hanya untuk guru namun juga dapat digunakan langsung oleh siswa. Data yang didapatkan kemudian dianalisis dengan menggunakan analisis deskrftif dengan mengacu kepada langkah-langkah yang dikemukakan [18]. Berdasarkan analisis data hasil pengisian angket oleh siswa, maka didapatkan nilai praktis dari media pembelajaran interaktif secara keseluruhan sebesar 87,5. Jika di interprestasikan dengan tabel nilai praktikalitas, maka praktikalitas media pembelajaran interaktif berdasarkan penilaian siswa berada pada taraf sangat praktis. Hasil analisis data praktikalitas media pembelajaran interaktif berdasarkan penilaian siswa untuk masing-masing item pernyataan angket disajikan pada tabel 5.

Tabel 5. Data Praktikalitas berdasarkan Respon Siswa

\begin{tabular}{ccl}
\hline Item & $\begin{array}{c}\text { Nilai } \\
\text { Praktikalitas }\end{array}$ & Interprestasi \\
\hline 1 & 88 & Sangat Praktis \\
2 & 90 & Sangat Praktis \\
3 & 88 & Sangat Praktis \\
4 & 82,7 & Sangat Praktis \\
5 & 92,7 & Sangat Praktis \\
6 & 87,3 & Sangat Praktis \\
7 & 91,3 & Sangat Praktis \\
8 & 88 & Sangat Praktis
\end{tabular}

\begin{tabular}{ccc}
9 & 77,3 & Praktis \\
10 & 89,3 & Sangat Praktis \\
11 & 85,3 & Sangat Praktis \\
12 & 88 & Sangat Praktis \\
13 & 85,3 & Sangat Praktis \\
14 & 88,7 & Sangat Praktis \\
15 & 86 & Sangat Praktis \\
16 & 92 & Sangat Praktis \\
\hline Total & 87,5 & Sangat Praktis \\
\hline
\end{tabular}

Berdasarkan tabel hasil analisis data pada tabel 5, maka dapat diketahui bahwa terdapat 15 item pernyataan angket berada pada taraf sangat praktis dan 1 item pernyataan angket berada pada taraf praktis, serta didukung dengan nilai total praktikalitas media pembelajaran interaktif yang berada pada taraf sangat praktis, dengan demikian maka media pembelajaran interaktif sangat praktis digunakan oleh siswa dalam proses pembelajaran Rangkaian Listrik. Sebaran data untuk masingmasing item praktikalitas berdasarkan respon siswa dapat dilihat pada grafik praktikalitas media berdasarkan respon siswa yang disajikan pada gambar 3.

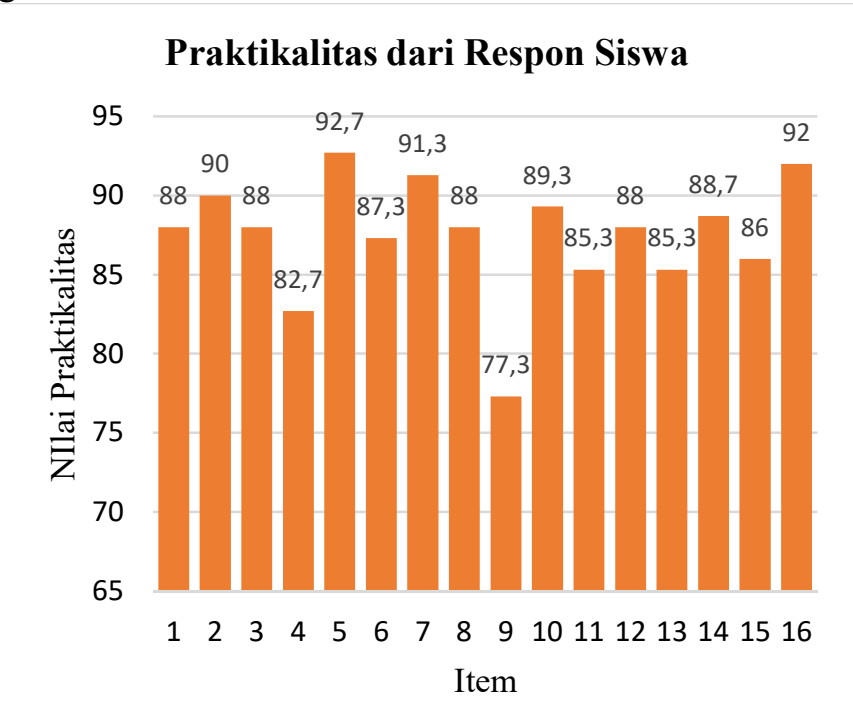

Gambar 3. Grafik Praktikalitas Media berdasarkan Respon Siswa

\section{KESIMPUlaN}

Hasil penelitian ini menyimpulkan bahwa tingkat praktikalitas media pembelajaran interaktif berdasarkan peniliaan guru setelah menggunakan media pembelajaran interaktif ini dalam proses pembelajaran Rangkaian listrik berada pada taraf praktikalitas yang sangat tinggi. Sedangkan, tingkat praktikalitas media pembelajaran interaktif berdasarkan penilaian siswa berada pada taraf praktikalitas yang sangat tinggi juga. Dengan demikian, dapat disimpulkan bahwa media 
pembelajaran interaktif memiliki tingkat praktikalitas yang sangat tinggi untuk digunakan oleh guru dan siswa pada proses pembelajaran Rangkaian Listrik. Sehingga media pembelajaran interaktif ini dapat dilaksanakan pengujian lanjut untuk lebih memastikan bahwa media pembelajaran interaktif dapat diterapkan dalam proses pembelajaran Rangkaian listrik secara menyeluruh.

\section{DAfTAR PUStaka}

[1] Ansyar, Rayandra, 2011, Kreatif Mengembangkan Media Pembelajaran, Gaung Persada, Jakarta.

[2] Chan H. S., Morgan S. (2015). Interactive Learning Media to Enhancing Student' Learning Process. Journal Of Education Research,18, 1467-1472. Amsterdam: Elsevier.

[3] Diergarten K. A., Mockel T., Nieding G., et al. (2017). The Impact of Media Literacy on Children's Learning from Films and Hypermedia. Journal Of Technical Education. 21, 33-41, Amsterdam: Elsevier.

[4] Hawlitschek A., Joeckel S. (2017). Increasing The Effectiveness of Digital Educational Games: The Effects of a Learning nstruction on Student' Learning, Motivaton and Cognitive Load. Journal of Education Research, 25, 1243-1251. Amsterdam: Elsevier.

[5] Prior, D. D., Mazanov, J., Meacheam, D., Heaslip, G., \& Hanson, J. (2016). Attitude, digital literacy and self-efficacy: Flow-on effects for online learning behavior. The Internet and Higher Education, 29, 91-97.

[6] Richardson, J. C., \& Swan, K. (2003). Examining social presence in online courses in relation to students' perceived learning and satisfaction. Journal of Asynchronous Learning Networks, $7(1), 68-88$.

[7] Larusson, J., Alterman, R., (2009). Wikis to support the collaborative part of collaborative learning. Journal of Computer \& Education, 4, 76-89, Amsterdam: Elsevier.

[8] Pintrich, P. R., Smith, D. A. F., Garcia, T., \& McKeachie, W. J. (1993). Reliability and predictive validity of the Motivated Strategies for Learning Questionnaire (MSLQ). Educational and Psychological Measurement, 53, 801-813.

[9] Rusman dkk., 2011, Pembelajaran Berbasis Teknologi Informasi dan Komunikasi, Rajawali Pers, Jakarta.

[10] Sugiyono, 2008, Metode Penelitian Pendekatan Kualitatif, Kuantitatif dan R\&D, Alfabeta, Bandung

[11] Hu, P.J., Chau, P.Y.K., Sheng, O.R.L., Tam, K.Y., (1999). Examining the technology acceptance model using physician acceptance of telemedicine technology. Journal Of Management and Information, 16, 91-112, The Kingdom Of Saudi Arabia : King Saud University.

[12] Andrizal, A., \& Arif, A. (2017). Pengembangan Media Pembelajaran Interaktif Pada Sistem ELearning Universitas Negeri Padang. INVOTEK: Jurnal Inovasi Vokasional Dan Teknologi, 17(2), 1-10.

[13] Janssen, J., Kirschner, F., Erkens, G., Kirschnker, P.A., Paas, F. (2010). Making the black box of collaborative learning transparent: combining process-oriented and cognitive load approaches. Journal of Education \& Psychology, 22, 139-154, The Kingdom Of Saudi Arabia: King Saud University.

[14] Kaplan, M., Haenlein, M. (2010). Users of the world, unite. The challenges and opportunities of Social Media. Journal of Computer dan Education. 53, 59-68, Amsterdam: Elsevier.

[15] Ahyanuardi, A., Hambali, H., \& Krismadinata, K. (2018). Pengaruh Kompetensi Pedagogik Dan Profesional Guru Sekolah Menengah Kejuruan Pasca Sertfikasi Terhadap Komitmen Guru Melaksanakan Proses Pembelajaran. Invotek: Jurnal Inovasi Vokasional Dan Teknologi, 18(1), 67-74.

[16] Kim, B., Kim, T., Shin, S.W. (2011). Understanding antecedents of continuance intention in social-networking services. Journal Of Behavior of Social Network, 14, 45-51. Amsterdam: Elsevier.

[17] Kirschner, A., Karpinski, C. (2010). Facebook and academic performance. Jounal Of Computer and Humaniora, 26, 1237-1245, The Kingdom Of Saudi Arabia: King Saud University.

[18] Riduwan, 2010, Skala Pengukuran VariabelVariabel Penelitian, Alfabeta, Bandung.

[19] Yanto, D. T. P., \& Sukardi, D. P. (2017). Effectiveness of interactive instructional media on electrical circuits course: the effects on students cognitive abilities. Proceeding: 4rd ICTVET, 112-116, Padang: Universitas Negeri Padang

[20] Sukardi, S., Puyada, D., Wulansari, R. E., \& Yanto, D. T. P. (2017). The validity of interactive instructional media on electrical circuits at vocational high school and technology. Proceeding : 2nd INCOTEPD, 123-126, Yogyakarta: Universitas Negeri Yogyakarta.

[21] Prince, M. (2004). Does Active Learning Work? A Review of the Research. Journal of Engineering Education, 93(3), 223-231.

[22] Kim, C.H., Robert, F. (2014). A fundamentals of Instructional media : A practical domain. Journal Of Computer \& Humaniora, 25, 113-119, The Kingdom Of Saudi Arabia: King Saud University.

[23] Helou, A.M., Rahim, N.Z.A. (2014). The influence of social networking sites on students' 
academic performance in Malaysia. International Journal of Electron. Malaysia: Commerce.

[24] Morgan,. R., Smith, D. A. F., Garcia, T., \& McKeachie, W. J. (2003). Enhance a learning process through a Interactive learning media). Educational and Psychological Measurement, 62, 701-713.

[25] Yanto, D. T. P., Aswardi, Habibullah, (2014), Penerapan Media Pembelajaran Interaktif Berbasis Animasi Flash pada Mata Pelajaran Pengukuran Listrik, Skripsi, Universitas Negeri Padang

[26] Yanto, D. T. P., Sukardi, Usmeldi, (2016), Pengembangan Media Pembelajaran Interaktif pada Proses Pembelajaran Rangkaian Listrik. Tesis, Universitas Negeri Padang.

[27] Djamarah, Syaiful Bahri, 1997, Strategi Belajar Mengajar, Rineka Cipta, Jakarta.

[28] Gan B., Menkhoff T., Smith R. (2015). Enhancing Student' Learning Process through Interactive Digital Media: New Oppotunities for Collaborative Learning. Journal Of Educational Research, 21, 1541-1552. Amsterdam: Elsevier.

[29] Gufron A., Jasman I. (2012). Peningkatan Hasil Belajar Peserta didik Menggunakan Media
Pembelajaran Interaktif pada Mata Pelajaran Fisika. Jurnal Pendidikan, 21, 21-25, Yogyakata: Universitas Negeri Yogyakarta.

[30] Muliyana, M., Habibullah, H., \& Myori, D. E. (2017). Pengembangan multimedia interaktif pada mata pelajaran dasar dan pengukuran listrik. INVOTEK: Jurnal Inovasi Vokasional dan Teknologi, 17(2), 113-118.

\section{Biodata Penulis}

Doni Tri Putra Yanto, lahir desa Cupak Kabupaten Kerinci Jambi, 16 April 1993. Lulus Sarjana pada Program Studi Pendidikan Teknik Elektro di Universitas Negeri Padang,Kota Padang, pada tahun 2014. Kemudian pada tahun 2016 memperoleh gelar Mater pada Program Studi Pendidikan Teknologi dan Kejuruan Kosentrasi Teknik Elektro di Univeristas Negeri Padang. Peneliti merupakan dosen tetap di Jurusan Teknik Elektro, Fakultas Teknik, Universitas Negeri Padang sejak tahun 2017. 